\title{
The impact of the financial crisis on European attitudes toward immigration
}

Correspondence:

joachim.v.isaksen@ntnu.no Department of Social Work, Norwegian University of Science and Technology, Trondheim, Norway

\begin{abstract}
This paper studies changes in attitudes toward immigration over a 10-year period, with an examination of the long-term effects of economic downturn.The focus is on changes before and after the financial crisis. I use data from the European Social Survey (2002-2014), combined with economic indicators at the country level. This intends to observe links between economic performance and attitudes with a comparative analysis of data from 25 European countries. Overall, European public appear to become less positive toward immigration during economic crisis, although there are notable variations among the countries. The results show more pessimistic attitudes toward the immigrations' contribution to the economy, especially in countries where the crisis had the most severe economic impact. Overall, the findings suggest that a downward economic spiral correlates with more negative attitudes towards immigration.
\end{abstract}

Keywords: Immigration, Financial crisis, Attitudes

\section{Introduction}

An increase in migration in most EU countries has taken place in recent decades. Simultaneously many European countries have experienced periods of economic instability. An increase in immigration together with the financial crisis of 2007-2008 makes it relevant to investigate changing attitudes among majority populations. Fluctuations in the economy frequently return to normal after a relatively short period. Occasionally, however, a downturn in the economy can result in economic performance remaining at a low level for many years and unemployment can remain stubbornly high. Simply put, the economy sometimes appears to be stuck, unable to return to normal (Blanchard, 2006). This is what happened during the financial crisis during 2007-2008. Most economists agree that early signs of the economic crisis were evident already in 2007 (Roth, 2009). The US housing boom began to deflate in the fall of 2005 but it took a while for most people to react to this. As prices rose to the point where purchasing a home became out of reach for many Americans, sales began to slacken off (Krugman, 2009). Quillian (1995) has argued that prejudice may increase in times of economic recession because the majority group tends to blame minority groups for the economic problems. Opposition towards minority groups can be triggered if the size of the minority group increases, especially if the majority feels that it has to compete for scarce resources or cultural hegemony. Against this background it is relevant to explore whether there has been increased resistance towards immigration in

(c) The Author(s). 2019 Open Access This article is distributed under the terms of the Creative Commons Attribution 4.0 International License (http://creativecommons.org/licenses/by/4.0/), which permits unrestricted use, distribution, and reproduction in any medium, provided you give appropriate credit to the original author(s) and the source, provide a link to the Creative Commons license, and indicate if changes were made. 
European countries subsequent to 2007-2008, as a response to the economic downturn. This paper explores changes in immigration attitudes from 2002 to 2014 in the light of developments reflected in macroeconomic measures over time. The data used is from the European Social Survey for the period 2002-2014 combined with economic indicators at the national level, from the World Bank (2017a, b, c), and The International Monetary Fund. The main purpose is to ascertain whether there has been a change in attitudes toward immigration before, during, and after the financial crisis. While many studies have focused on variations in immigration attitudes within and between countries, relatively few have focused on changing attitudes over time. There are nevertheless some exceptions, as for example Coenders and Scheepers's (1998) study of Dutch support for ethnic discrimination in the Netherlands 1979-1993, as well as their study of changes in resistance to the social integration of foreigners in Germany 19802000. In addition Semyonov, Raijman, and Gorodzeisky's (2006) studied the rise of anti-foreigner sentiment in European societies, 1988-2000. However, these studies have not initially looked at immigration attitudes in relation to economic data. The contribution of the present article is to show the long-term relationship between economic performance and attitudes toward immigration in 25 European countries. The large sample of countries makes it possible to undertake a comparative approach. I analyze the changes in attitudes in the light of macroeconomic factors such as growth in GDP, GDP per capita, and unemployment rate, in order to identify to what extent economic factors might be associated with negative attitudes toward immigration.

\section{Research on attitudes toward immigration}

Different terms have been used to refer to attitudes toward immigration. The literature presents a rich variety of definitions, and a large number of different theoretical concepts have been used in the previous studies. Perhaps the most commonly used, particularly in American research, is "prejudice" (e.g., Quillian, 1995), but other terms, such as 'anti-foreigner sentiment' (Semyonov et al., 2006) and "ethnic exclusionism" (Scheepers, Gijberts, \& Coenders, 2002), are also widespread. Negative attitudes toward other ethnic groups is often named "ethnic prejudice" (Quillian, 1995), while other common terms are ethnic intolerance and anti-immigration attitudes. One of the most used definitions of the concept is Allport's (1954) that defines ethnic prejudice as an antipathy based upon a faulty and inflexible generalization. It may be directed toward a group as a whole, or toward an individual because he is a member of that group. For the purpose of this study, I use negative attitudes towards immigration, but the use of the concept does not necessarily imply ethnic prejudice, since the question is seen in relation to how immigration influences the economy. One could argue that a person might be positive toward immigrants as a group, but simultaneously have negative perceptions of immigration as seen from an economic perspective.

Contextual factors may influence negative attitudes toward immigration as well as different ethnic groups. Several studies show that individuals who are socially and economically vulnerable feel more threatened by the presence of minorities, and are more likely to express discriminatory and exclusionary attitudes (Espenshade \& Hempstead, 1996; Raijman, Semyonov, \& Schmidt, 2003; Semyonov, Raijman, Yom-Tov, \& Schmidt, 2004). These findings are in line with the group threat argument first proposed by Blalock (1967), and that for the purpose of the present study, implies that economic 
recessions will lead to more people being in direct or potential competition over resources across group boundaries. This competition can lead to more hostile attitudes towards members of other groups. Various studies have also shown this effect to be present regarding the positive association between out-group size and in-group prejudice (Fosset \& Kiecolt, 1989; Semyonov et al., 2006). Quillian (1995) is well known for a groundbreaking study of prejudice toward foreigners in 12 European countries. The results show that most of the variation in average prejudice scores across these countries could be attributed to group threat. Scheepers et al. (2002) have performed large studies on exclusionary attitudes toward foreigners in 15 countries, while Evans and Need's (2002) analyzed attitudes toward minorities' political rights in 13 East European countries. Gijsberts, Scheepers, and Coenders (2004) focused on nationalism and exclusion of migrants in 22 European countries. Turner and Cross's (2015) observed changing ethnic attitudes in Ireland during recession. This study compares Ireland with 12 European countries, and investigates variations between countries in view of economic fluctuations. Czaika and Di Lillo (2018) have performed a study of regional variations in anti-immigrant attitudes across Europe in the period 2002-2014. One of the main findings was that the identification of a spatially dependent process in the diffusion and clustering of anti-immigrant attitudes may explain the rise and fall of populist movements across Europe and changing electoral support for anti-immigration parties across European regions over time. They argue that a clustering of populations with anti-immigrant attitudes takes place when people with more liberal attitudes move to regions with a greater presence of like-minded others, while those with more nativist attitudes also do the same. This may lead, at least to some extent and only in the long term, to a "population resorting" along attitudinal categories creating spatially more homogeneous clusters of anti-immigrant populations. Even if Czaika and Di Lillo (2018) emphasize influences from the surroundings, they also mention economic hardship as an important factor.

\section{Immigrants as scapegoats in times of economic pressure}

The scapegoat theory refers to the tendency to blame someone else for one's own problems (Macionis \& Plummer, 2008). According to Savelkoul, Scheepers, Tolsma, and Hagendoorn (2011) such emotions may increase during times of crisis, leading to an increase in negative attitudes directed toward immigrants. First of all, frustration against weak minority groups may take place, where these groups are labeled as scapegoats. Second, increased competition may reinforce group mentality and the need to identity with one's own in-group which is trying to distance itself from out-groups. For the purpose of this study, scapegoating can serve as an opportunity to explain personal failures or misdeeds while maintaining one's positive self-image during the financial crisis. A person who is poor, or does not get a job that he or she applies for, can choose to blame the people who did get the job that he or she wanted. The person may be using others as a scapegoat and end up with resentment as a result. The scapegoat theory states that prejudice towards other ethnicities is often strongest among individuals in the majority population who have fewer resources, and direct frustration toward groups that are relatively safe to refer to in a negative manner (Macionis \& Plummer, 2008). The scapegoat theory states that individuals who fear job competition from immigrants tend to be those employed in low-skill, low-wage occupations. However, there is also a 
broader segment of the population which is concerned with possible negative implications of large-scale immigration on macroeconomic performance (Moehring, 1988). Half of those responding in a 1986 national poll identified economic issues as "the biggest problem" immigrants have caused. Typical of the kinds of problems mentioned, are strains on jobs, resources, and housing; immigrants on welfare; and cheap labor (Day, 1990). The most common adjectives used to describe migrants were "poor" and "welfare-dependent" (Pear, 1986). Following this logic one assumption is that an increase in level of frustration toward immigration can be one result of the financial crisis. This could lead to more negative attitudes toward immigrants, especially in countries with the weakest economies.

\section{Ethnic competition}

The scapegoat theory resembles ethnic competition theory, which has often been used to account for negative attitudes toward minority groups. Ethnic competition is another commonly used explanation for negative attitudes toward immigration. During recessions, feelings of ethnic competition may increase. On an individual level various studies suggest that lower-skilled natives are particularly more likely to have anti-immigrant attitudes since they compete with low-skilled immigrants (Scheve \& Slaughter, 2001). However, Meuleman, Davidov, and Billiet (2009) have found that it is not the degree of competition by itself that may affect out-group attitudes, but rather the extent to which competition fluctuate. Consequently, attitudes toward immigration are more likely to change when sudden changes occur in economic conditions. One main reason is that rapid economic change can affect labor demand more dramatically than slow-paced evolution.

Early studies have also shown a link between economic fluctuation and ethnic hostility. According to Blumer (1958) and Blalock (1967) prejudice and hostility toward a minority population increases with a rise in competitive threat associated with an increase in the size of an out-group population. That is, hostility and prejudice against outsiders are expected to rise, especially among economically vulnerable populations when the minority group is expanding and when economic conditions in the country are deteriorating. The realistic group conflict theory explains how intergroup hostility arises as a result of conflicting goals and competition over limited resources (Jackson, 1993). Realistic group conflict theory has support from several empirical studies. For example, optimistic evaluations of personal economic well-being are related to positive attitudes toward immigration (Kehrberg, 2007). Some theories on ethnic relations state that economic threat engenders opposition to immigration. Olzak's (1992) model of ethnic competition emphasizes the influence of a shrinking job market on native workers, while relative deprivation theory (Gurr, 2011; Runciman, 1966) stress the influence of group comparisons on discontent. The structural factors stimulating a heightened sense of economic vulnerability may vary depending on the context. One may be or feel insecure in relation to the labor market, housing market, or the continued supply of government benefits (Hernes \& Knudsen, 1992). In a global economy, the exchange of cross-border goods, capital, and labor make the working force vulnerable to sudden economic changes. Dancygier and Donnelly (2014) suggest that economic conditions may influence native ethnic attitudes. They point out that during a recession, native workers may view the inflow of immigrants into their sectors as economically 
threatening to themselves and their co-workers. In short, they point out that immigrants fill the need of low-wage labor to a larger degree than the native population. On the other hand, if immigrants seek employment in economies that are growing, they may provide the necessary contribution to meet rising demand. In such cases, the native workers may not risk losing their jobs and any potential negative effect on their wages may be disguised by an increase in wages since potentially higher wages that would have arrived in the absence of migration are never observed (Dancygier \& Donnelly, 2014). However, during times of recession the low-wage labor workforce may simultaneously experience a further decline in their wages and a decreased demand for workers. The combination of these two factors may increase feelings of competition from out-groups. Ethnic competition can be understood as a function of the in-groupout-group relationship, and can take place within the economy as well as within welfare services and jobs (Coenders \& Scheepers, 2008; Kunovich, 2004; Mayda, 2006). A sum up of research suggests that the impact on the labor market resulting from immigration is worse for natives during economic downturns than during expansions. For example, Peri (2010) finds that when the economy is growing, immigration creates jobs in sufficient numbers to leave native employment unaffected. During downturns, however, the economy does not appear to respond as quickly. Therefore, he argues that the national economy benefits most from immigration that adjusts to economic conditions. In this respect, the low-wage native work force experiences increased threat from migration during periods of worsened economic conditions. Research also indicates that prosperous countries are less susceptible to recessions when it comes to changing attitudes toward immigration.

Based on the ethnic competition theory and scapegoat theory one might expect to find that immigrants are more likely to be blamed during times of economic pressure. The data material will show whether changes in national performance on economic indicators influence immigrant attitudes. I expect that countries that are the most affected by the economic crisis display the largest increase in negative immigrant attitudes. Although, it might not be only the economic per se, but also the shape of the economy before an economic crisis.

While ethnic competition theory and scapegoat theory emphasize economic factors such as employment level, competition on the labor market from immigrants, and GDP growth, social theories focus more on social influence. The social impact theory states that when other people are the source of impact and the individual is the target, impact should be a multiplicative function of the strength, immediacy, and number of other people. It is a broad theory, which seeks to encompass a variety of thoughts, feelings, and behaviors. When other people are sources of social influence on a target person, impact is predicted to be a multiplicative function of the strength, immediacy, and number of sources (Latané, 1981). The implications are that people first and foremost are influenced by their immediate surroundings, such as people living in the same neighborhood. Accordingly, people who are geographically distant do not have a substantial social impact on the individual. This argument implies that variations in immigration attitudes are more dependent on social factors at the micro level, rather than macroeconomic factors. As such, it would be relevant to explore regional variations in attitudes, since social factors may influence the individual independently of national macroeconomic fluctuations. Following this logic, it is reasonable that some of the 
variations on attitudes is due to micro factors. Although, financial crisis was a large scale event where the impact was not restricted just to certain regions, but rather had an impact on nations as a whole. Accordingly, I firmly believe that macroeconomic factors represent a solid indicator for attitudinal variations.

\section{The importance of long term economic development}

According to Inglehart (1990) the post-materialistic development in Europe implies that people in countries with the highest economic standards have the most tolerant values. Post-materialism is a value orientation that emphasizes self-expression and quality of life over economic and physical security. Further, Inglehart (1990) suggests that until the 1970s, it was almost universal for individuals to prioritize so-called materialist values such as economic growth and maintaining order. After the rise in prosperity, post-materialists started to prioritize such goals as environmental protection, freedom of speech, and gender equality. The shift, particularly among citizens living in Western countries, reflected a change from an environment in which one was aware that survival was precarious, to a post-World War II world where most felt that survival could be taken for granted. Further, conditions of prosperity and security are conducive to tolerance of diversity in general and democracy in particular. This helps explain a long-established finding: rich societies are much more likely to be more democratic than poor ones. One contributing factor is that the authoritarian reaction is strongest under conditions of insecurity.

Building on Inglehart's post-materialistic diagnosis, I assume that higher standards of living reduce the influence of the group threat mechanisms proposed by Blalock (1967). Similar to Inglehart (1990), I also focus on the national context. Nevertheless, there might be economic variations between nations as well as variations over time. I therefore assume that variations in attitudes are dependent on the GDP per capita and unemployment rate.

\section{Data and method}

To investigate whether there is an association between economic fluctuations and attitudes I use data spanning from 2002 to 2014, covering 25 European countries, based on six rounds of the European Social Survey (ESS). The data is from the European Social Survey for 2002, 2004, 2006, 2008, 2010 and 2014 rounds. Rounds 2002, 2004, and 2006 are included to reduce the possibility that the numbers found are a continuation or exacerbation of an earlier trend. The years following the outbreak of the crisis are also included in order to evaluate the long-term trends. The method employed is time series data with two levels; individual and country-year. The time series is used in order to identify changes in attitudes over time, and the data consists of countries with different experiences from the 2008 financial crisis. First, there are those countries which have been most affected (Greece, Spain, Italy etc.). Second, we have those who have been relatively moderately affected (Norway, Sweden, Germany etc.). The financial crisis can be seen as an exogenous event and may be viewed as a natural experiment, where I argue that economic fluctuations is one of the main factors that can influence a change in attitudes. Immigration attitudes are analyzed in light of changes in economies based on indicators gathered from the World Bank (2017a, b, c) and the International Monetary Fund. 


\section{Dependent variable}

In the ESS data set there are several questions that measure how respondents evaluate migrants. One question measures attitudes to the allowance of professionals from a poor country outside Europe. Another measures attitudes to the allowance of people from the poorer countries in Europe, while one asks the respondents whether they think one should allow people from the poorer countries outside of Europe. While these questions measure attitudes in different context, I found it useful to focus on a variable that is more specifically related to the economic dimension. According to the economic decline, I expect an increase in negative attitudes toward immigration from 2008 to 2014, and as dependent variable, I use the measure Immigration good or bad for the economy (1-10) where higher values indicate that respondents evaluate immigration as being good for the economy. I consider this variable to be a precise measure of long term changes in a country's economic situation since it captures the economic aspect of the question. That is, it measures whether or not the respondent views outsiders as a threat to the economy rather than being a resource. The variable is from the European Social Survey and is repeatedly asked in 2002, 2004, 2006, 2008, 2010, 2012, and 2014. This variable also correlates with other variables commonly used to measure various dimensions of immigration attitudes.

\section{Economic indicators}

Economic indicators provide statistical information about economic activity during cycles. In order to identify whether economic performance affects levels of tolerance, I examine attitude formation in the light of the country's scores on macroeconomic indicators over time. GDP is an indicator for total value added in a country, and also provides us with an expression of gross income from domestic production activity (World Bank, 2017a, b, c). GDP growth is the annual percentage growth rate of GDP per capita based on constant local currency (World Bank, 2017a, b, c). The per capita GDP is especially useful when comparing one country with another, as it shows the relative performance of the countries. A rise in per capita GDP signals growth in the economy and tends to reflect an increase in productivity. For the purpose of this study, it is useful to use the GDP per capita since the aim is to compare countries. While GDP refers to the total value of gods and services produced within a country's borders annually, GDP growth measures how fast the economy is growing. Level of employment is another commonly used indicator of the state of the economy. In many countries the unemployment reached critical levels after the financial crisis Krugman (2012). Low unemployment indicates that there is pressure on the labor market. Trends in the unemployment rate reflect the state of the economy, but the effect does not manifest itself immediately (World Bank, 2017a, b, c).

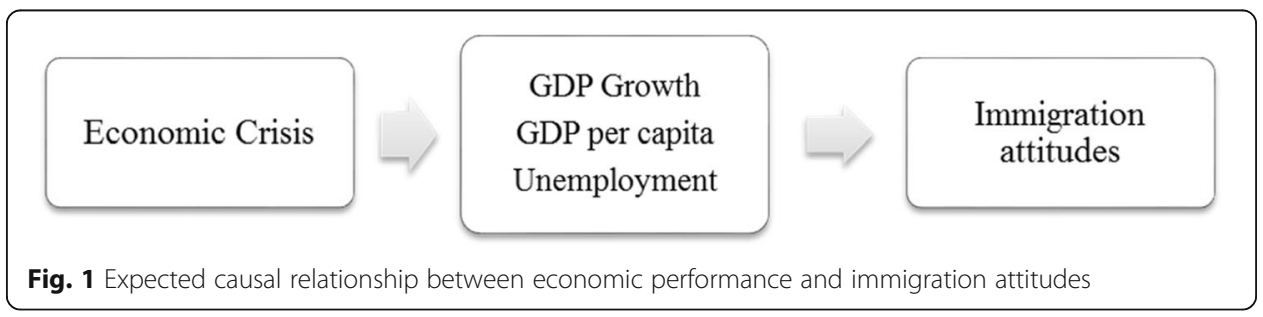


Figure 1 illustrates the expected causal relationship between economic performance and immigration attitudes. For the purpose of this study I assume that the consequence of economic crisis where the macroeconomic measures change in a negative direction, may in turn impact attitude formation. The financial crisis is viewed as a natural experiment where a change in immigration attitudes after 2007 can be understood in view of the crisis.

In the following sections I will present tables with the numbers from the three economic indicators, GDP growth, GDP per capita, and unemployment rate.

Table 1 shows that GDP growth decreased in all 25 countries, between 2007 and 2009. Some countries experienced a more severe decrease than others, but the overall trend is negative. The table shows that the countries with the best performance are Poland, Norway, Cyprus, Switzerland, and Belgium. Slovenia, Russia, Finland, Estonia, and Ukraina have the most negative development. There are no clear trends in what geographical region the countries with the best performance on GDP growth originate from. Although, the worst performing countries are eastern European countries, with the exception of Finland. Until fall 2008, the Eastern European countries had enjoyed a prosperous decade.

Table 1 GDP growth (in percent of GDP)

\begin{tabular}{|c|c|c|c|c|c|c|}
\hline & 2003 & 2005 & 2007 & 2009 & 2011 & 2013 \\
\hline Belgium & 0.775 & 2.094 & 3.449 & -2.253 & 1.798 & 0.201 \\
\hline Bulgaria & 5.078 & 7.236 & 7.675 & -3.586 & 1.915 & 0.862 \\
\hline Croatia & 5.558 & 4.164 & 5.150 & -7.384 & -0.281 & -1.064 \\
\hline Cyprus & 2.476 & 3.724 & 4.281 & -1.772 & 0.321 & -5.934 \\
\hline Czech Repub. & 3.603 & 6.533 & 5.603 & -4.803 & 1.778 & -0.484 \\
\hline Denmark & 0.390 & 2.337 & 0.909 & -4.907 & 1.337 & 0.933 \\
\hline Estonia & 7.416 & 9.374 & 7.748 & -14.724 & 7.597 & 1.937 \\
\hline Finland & 1.994 & 2.780 & 5.185 & -8.269 & 2.571 & -0.758 \\
\hline France & 0.820 & 1.608 & 2.361 & -2.941 & 2.079 & 0.576 \\
\hline Germany & -0.710 & 0.707 & 3.261 & -5.619 & 3.660 & 0.490 \\
\hline Greece & 5.795 & 0.599 & 3.274 & -4.301 & -9.132 & -3.241 \\
\hline Hungary & 3.849 & 4.388 & 0.435 & -6.600 & 1.662 & 2.096 \\
\hline Ireland & 3.120 & 6.006 & 5.209 & -4.627 & 2.985 & 1.639 \\
\hline Netherlands & 0.284 & 2.160 & 3.698 & -3.768 & 1.664 & -0.190 \\
\hline Norway & 0.920 & 2.625 & 2.985 & -1.691 & 0.972 & 1.044 \\
\hline Poland & 3.562 & 3.494 & 7.035 & 2.820 & 5.017 & 1.392 \\
\hline Portugal & -0.934 & 0.767 & 2.492 & -2.978 & -1.827 & -1.130 \\
\hline Russia & 7.796 & 6.376 & 8.535 & -7.821 & 5.285 & 1.785 \\
\hline Slovakia & 5.419 & 6.751 & 10.800 & -5.423 & 2.819 & 1.491 \\
\hline Slovenia & 2.842 & 4.003 & 6.942 & -7.797 & 0.649 & -1.132 \\
\hline Spain & 3.188 & 3.723 & 3.769 & -3.574 & -0.999 & -1.706 \\
\hline Sweden & 2.386 & 2.818 & 3.405 & -5.185 & 2.664 & 1.241 \\
\hline Switzerland & 0.040 & 3.115 & 4.112 & -2.222 & 1.693 & 1.852 \\
\hline Ukraine & 9.400 & 2.700 & 7.900 & -14.800 & 5.466 & -0.027 \\
\hline United King. & 3.326 & 3.096 & 2.357 & -4.188 & 1.453 & 2.052 \\
\hline
\end{tabular}


Table 2 GDP per capita (current US\$)

\begin{tabular}{|c|c|c|c|c|c|c|}
\hline & 2003 & 2005 & 2007 & 2009 & 2011 & 2013 \\
\hline Belgium & $30,743,9$ & $36,967,3$ & $44,403,8$ & $44,880,6$ & $47,702,8$ & $46,582,7$ \\
\hline Bulgaria & 2710,5 & 3893,7 & 5932,9 & 6969,6 & 7813,8 & 7674,9 \\
\hline Croatia & 7805,9 & $10,224,3$ & $13,546,7$ & $14,157,1$ & $14,539,2$ & $13,574,7$ \\
\hline Cyprus & $20,293.4$ & $25,324,5$ & $31,386,6$ & $32,105,8$ & $32,233,8$ & $27,908,0$ \\
\hline Czech Repub. & 9773,1 & $13,346,2$ & $18,373,7$ & $19,741,6$ & $21,717,5$ & $19,916,0$ \\
\hline Denmark & $45,458,8$ & $48,799,8$ & $58,487,0$ & $58,163,3$ & $61,753,7$ & $61,191,2$ \\
\hline Estonia & 7174,7 & $10,338,3$ & $16,586,4$ & $14,726,3$ & $17,454,8$ & $19,072,2$ \\
\hline Finland & $32,816,2$ & $38,969,2$ & $48,288,5$ & $47,107,2$ & $50,790,7$ & $49,638,1$ \\
\hline France & $29,691,2$ & $34,879,7$ & $41,600,6$ & $41,631,1$ & $43,810,2$ & $42,554,1$ \\
\hline Germany & $30,360,0$ & $34,696,6$ & $41,814,8$ & $41,732,7$ & $46,810,3$ & $46,530,9$ \\
\hline Greece & $18,477,6$ & $22,551,7$ & $28,827,3$ & $29,711,0$ & $25,916,3$ & $21,874,8$ \\
\hline Hungary & 8423,4 & $11,206,0$ & $13,907,5$ & $13,029,9$ & $14,118,1$ & $13,667,7$ \\
\hline Ireland & $41,107,0$ & $50,878,6$ & $61,359,6$ & $52,104,0$ & $52,224,0$ & $52,060,5$ \\
\hline Netherlands & $35,245,2$ & $41,577,2$ & $51,241,3$ & $51,900,3$ & $53,540,6$ & $51,574,5$ \\
\hline Norway & $50,111,7$ & $66,775,4$ & $85.170,9$ & $80,067,2$ & $100,711,2$ & $103,059,3$ \\
\hline Poland & 5693,5 & 8021,3 & $11,260,3$ & $11,542,0$ & $13,890,7$ & $13,780,2$ \\
\hline Portugal & $15,772,7$ & $18,784,9$ & $22,780,1$ & $23,064,0$ & $23,196,2$ & $21,618,7$ \\
\hline Russia & 2975,1 & 5323,5 & 9101,3 & 8562,8 & $14,212,1$ & $15,543,7$ \\
\hline Slovakia & 8696,1 & $11,669,4$ & $16,057,7$ & $16,513,0$ & $18,187,2$ & $18,191,6$ \\
\hline Slovenia & $14,880,5$ & $18,169,2$ & $23,841,3$ & $24,633,8$ & $24,985,2$ & $23,357,9$ \\
\hline Spain & $21,495,7$ & $26,510,7$ & $32,709,4$ & $32,334,0$ & $31,835,3$ & $29,211,8$ \\
\hline Sweden & $36,961,4$ & $43,085,4$ & $53,324,4$ & $46,207,1$ & $59,593,3$ & $60,283,2$ \\
\hline Switzerland & $48,087,6$ & $54,952,7$ & $63,555,2$ & $69,927,47$ & $88,415,6$ & $85,112,5$ \\
\hline Ukraine & 1048,5 & 1828,7 & 3068,6 & 2545,5 & 3569,8 & 4029,7 \\
\hline United King. & $34,174,0$ & $41,732,6$ & $50,134,3$ & $38,262,2$ & $41,412,3$ & $42,724,1$ \\
\hline
\end{tabular}

From Table 2 we see that GDP per capita is lower in 13 of the 25 countries in 2009 compared to 2007. The financial crisis had a different impact on the various European countries. However, the macroeconomic indicators show a clear overall picture: all countries in this sample were affected by economic fluctuations to various degrees. Although, the impact is highly uneven across nations. Data from the World Bank (2017a, b, c) also shows that Germany, the Netherlands, and the Scandinavian countries, for example, are relatively unaffected, while countries such as Greece, Spain, and Ireland continue to experience recession. Table 1 shows that all countries except for Poland had a negative GDP growth in the period 2007-2009. Simultaneously many countries had a positive growth in GDP per capita (see Table 2). When one presents the numbers from the period 2007-2009, it may seem like Tables 1 and 2 give contrasting evidence where GDP in some countries is negative while per capita income is not affected. When the numbers are presented in a 2-year period, they will not capture this trend. World Bank data (2017a, b and c) shows that it was a substantial fall in GDP growth from 2008 to 2009, and this will not manifest in Table 2 since it does not display the numbers in the period 2007-2008 and onwards. Although, the reason that I present data from a 2-year period for these indicators is that it is more purposeful for the data analysis. 


\section{Development in unemployment levels}

Some of the more frequent complaints about immigrants are that they take jobs away from native workers, contribute to higher unemployment, and reduce wages and lower working conditions in selected occupations. Job-holders at the bottom of the socioeconomic ladder are assumed to be most susceptible to these forms of labor market competition because low-skill and low-wage native workers have occupational characteristics similar to those of today's new immigrants (Borjas \& Freeman, 1992; Simon, 1987). Some researchers have found that education, income, and occupational prestige are positively correlated with receptivity to immigration (Hoskin \& Mishler, 1983; Simon, 1987). This has been especially prevalent in the light of the ongoing financial crisis. Since 2007-2008 Europe has experienced an economic crisis and frustration among the citizens has been increasing. The crisis has resulted in millions of people losing their jobs, and has set the world economy back for years. It is widely assumed that the long-standing economic crisis will increase negative attitudes toward immigration among the majority population in a country since this will increase the competition for jobs and other resources (Savelkoul et al., 2011).

Table 3 shows that the unemployment increased in most countries from 2007 to 2009, and that this negative trend continued in many countries throughout 2013. Some

Table 3 Unemployment (yearly in percent)

\begin{tabular}{|c|c|c|c|c|c|c|}
\hline & 2003 & 2005 & 2007 & 2009 & 2011 & 2013 \\
\hline Belgium & 7.7 & 8.4 & 7.5 & 7.9 & 7.1 & 8.4 \\
\hline Bulgaria & 13.7 & 10.1 & 6.9 & 6.8 & 11.3 & 12.9 \\
\hline Croatia & 13.9 & 12.6 & 9.9 & 9.2 & 13.7 & 17.3 \\
\hline Cyprus & 4.1 & 5.3 & 3.9 & 5.4 & 7.9 & 15.9 \\
\hline Czech Repub. & 7.5 & 7.9 & 5.3 & 6.7 & 6.7 & 7.0 \\
\hline Denmark & 5.4 & 4.8 & 3.8 & 6.0 & 7.6 & 7 \\
\hline Estonia & 11.3 & 8.0 & 4.6 & 13.5 & 12.3 & 8.6 \\
\hline Finland & 10.5 & 8.4 & 6.9 & 8.2 & 7.8 & 8.2 \\
\hline France & 8.8 & 8.9 & 8.1 & 9.1 & 9.2 & 10.4 \\
\hline Germany & 9.8 & 11.2 & 8.7 & 7.7 & 5.8 & 5.2 \\
\hline Greece & 9.4 & 10.0 & 8.4 & 9.6 & 17.9 & 27.5 \\
\hline Hungary & 5.8 & 7.2 & 7.4 & 10.0 & 11.0 & 10.2 \\
\hline Ireland & 4.5 & 4.3 & 4.7 & 12.0 & 14.6 & 13.0 \\
\hline Netherlands & 3.6 & 4.7 & 3.2 & 3.4 & 5.0 & 7.2 \\
\hline Norway & 4.2 & 4.4 & 2.5 & 3.1 & 3.2 & 3.4 \\
\hline Poland & 19.4 & 17.7 & 9.6 & 8.2 & 9.6 & 10.3 \\
\hline Portugal & 6.1 & 7.6 & 8.0 & 9.4 & 12.7 & 16.2 \\
\hline Russia & 8.2 & 7.1 & 6.0 & 8.3 & 6.5 & 5.5 \\
\hline Sweden & 5.6 & 7.5 & 6.2 & 8.4 & 7.8 & 8.1 \\
\hline Slovakia & 17.1 & 16.3 & 11.1 & 12.0 & 13.6 & 14.2 \\
\hline Slovenia & 6.5 & 6.5 & 4.8 & 5.9 & 8.2 & 10.1 \\
\hline Switzerland & 4.1 & 4.4 & 3.7 & 4.1 & 4.4 & 4.8 \\
\hline Spain & 11.3 & 9.1 & 8.2 & 17.9 & 21.4 & 26.1 \\
\hline Ukraine & 9.1 & 7.2 & 6.4 & 8.8 & 7.9 & 7.2 \\
\hline United King. & 4.8 & 4.8 & 5.3 & 7.5 & 8.0 & 7.5 \\
\hline
\end{tabular}


countries stand out more than others, for example Denmark, Estonia, Ireland, and Spain. In other countries we observe that the negative trend continues throughout 2011 and 2013, especially prevalent in Croatia, Cyprus, Greece, Portugal, and Spain. This means that when it comes to unemployment, countries in some parts of Europe have been quite dramatically affected by the crisis. Norway, The Netherlands, Switzerland, Cyprus and Slovenia are the countries with the lowest increase in unemployment. Numbers from 2009 show a dramatic difference between Norway that has the lowest unemployment (3.1\%), and Spain with the highest unemployment rate (17.9\%).

\section{Immigration attitudes over time}

The starting point of the study is that the financial crisis can be viewed as a natural experiment where a change in attitudes after 2007 can be attributed to the crisis. In the following section I present data on European attitudes over time where countries are grouped into five different catagories. The groups are categorized as follows: Category 1) The least affected countries, Category 2) The second least affected countries, 3) Moderately affected countries, 4) Highly affected countries, and 5) Most affected countries. The data spans from 2002 to 2014, and the time variation is illustrated on graphs (Fig. 2).

\section{The least affected countries}

Category 1 contains of the countries that were least affected by the economic crisis. These countries show a relatively stable pattern of attitudes over time, and the impact of the crisis is mildly related to attitudinal changes. Although we observe that the countries with the most stable economic performance over time, also show most positive toward immigration, with Switzerland being the country that display the most positive attitudes since 2008. Switzerland had a minor increase in unemployment and a moderate decrease in GDP growth during the period (World Bank, 2017a, b, c). Overall, the immigrant attitudes in Norway, Netherlands, and Denmark show a similar pattern from 2002 to 2014. They display a minor increase in negative attitudes in the years following the crises. Denmark had the highest rise

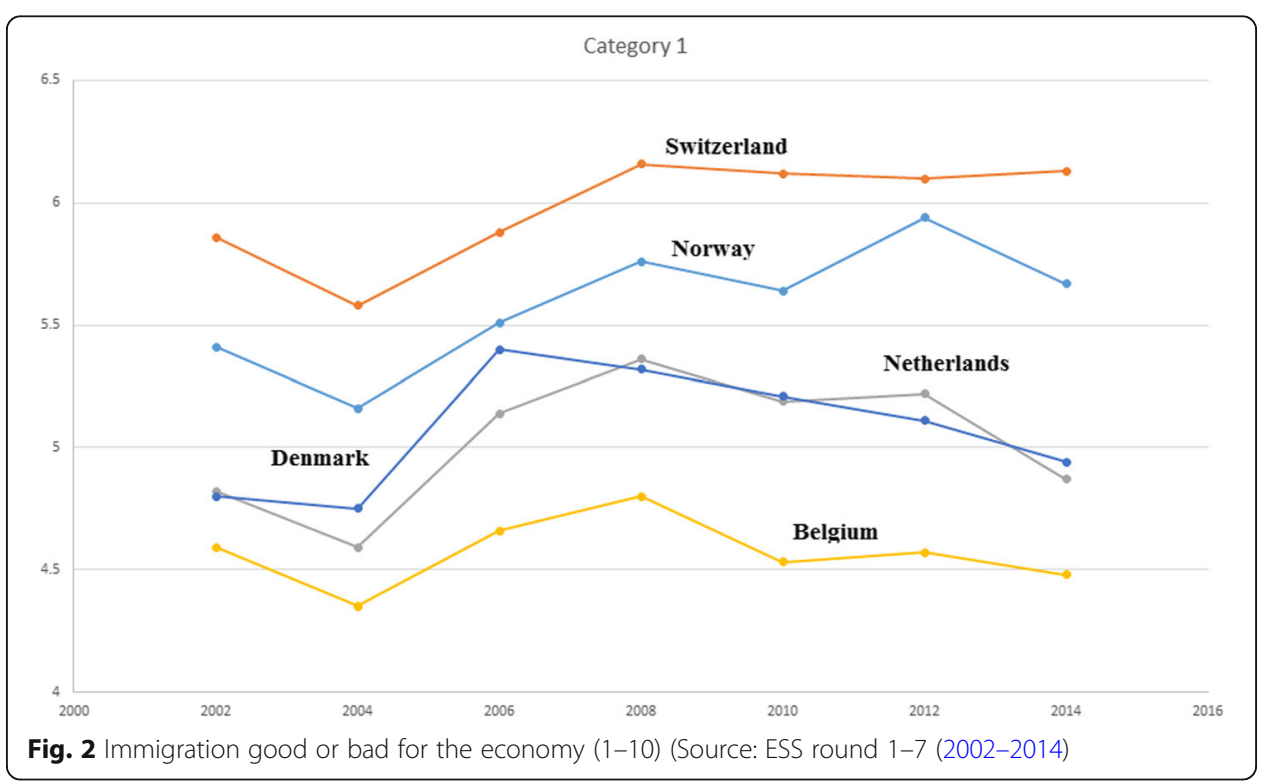


in negative attitudes, something that can be attributed to a substantial increase in unemployment in the years 2007-2009, compared with the other countries in category 1 (World Bank, 2017a, b, c). Overall, and despite some economic fluctuations, the financial crisis was only modestly associated with changes in attitudes in category 1 . One explanation can be that these countries also had prosperous economies before the crisis. Especially Norway and Denmark, and to a certain extent the Netherlands, are also characterized by having robust welfare models which provide the citizens with a fair amount of economic security during economic hardship. Several studies in economic growth literature in recent years have also found social trust to be an important and robust determinant, and especially the Scandinavian countries have traditionally been high in levels of trust (see for example Kroknes, Jakobsen, \& Grønning, 2015). Overall, countries with the most stable economic performance display little impact on immigration attitudes (Fig. 2).

\section{The second least affected countries}

Category 2 contains of countries in the data with the second best economic performance. Although all of these countries experienced negative impact on development measured by the macroeconomic indicators, there are still some variations (World Bank, 2017a, b, c). The pattern in Poland, France and United Kingdom changed litte from 2008 to 2014. Cyprus was the country with the largest increase in negative attitudes from 2006 to 2012, and also had the largest rise in unemployment (see Table 3). Despite that UK also had a decrease in GDP between 2007 and 2009, and an increase in the unemployment level (from 5.20 to $7.70 \%$ ), immigration attitudes were quite stable in the same period. These results are also in line with Turner and Cross's (2015) study which compares European attitudes before and after the crisis (2002 and 2010). Countries that have relatively stable economies are not so vulnerable to sudden change. Exactly like Cyprus, Finland also had a substantial rise in unemployment (6.9 to 8.2\%) in the period 2007 to 2011 (see Table 3). Finland, on the other hand, had a moderate increase in negative immigrant attitudes. One explanation can be that Finland is a Nordic country that is comparable to the Scandinavian countries where highly developed welfare states protect inhabitans against the most severe consequences of sudden economic changes. One the opposite, the case of Cyprus is more similar to other Southern European countries with weaker welfare states, where a larger increase of negative attitudes took place during and after the crisis (Fig. 3).

\section{Moderately affected countries}

Overall, the countries in this group have been moderately affected by the crisis. Although, Ireland is one of the countries in Europe that has been mostly affected, with an increase in unemployment by 125\% from 2007 to 2009 (World Bank, 2017a, b, c), while youth unemployment approached 30\% (Krugman, 2009). This negative spiral may have been a contributing factor to an increase in negative attitudes. Ireland has on the opposite shown more positive attitudes during periods of lower unemployment. There was a clear increase in negative attitudes commencing in 2006, reaching its lowest point in 2010. Positive attitudes increased after 2010, simoultaneously as the economy started to recover. In Sweden positive attitudes toward immigration was the trend from 2004 to 2010. Although, the attitudes were even more positive 


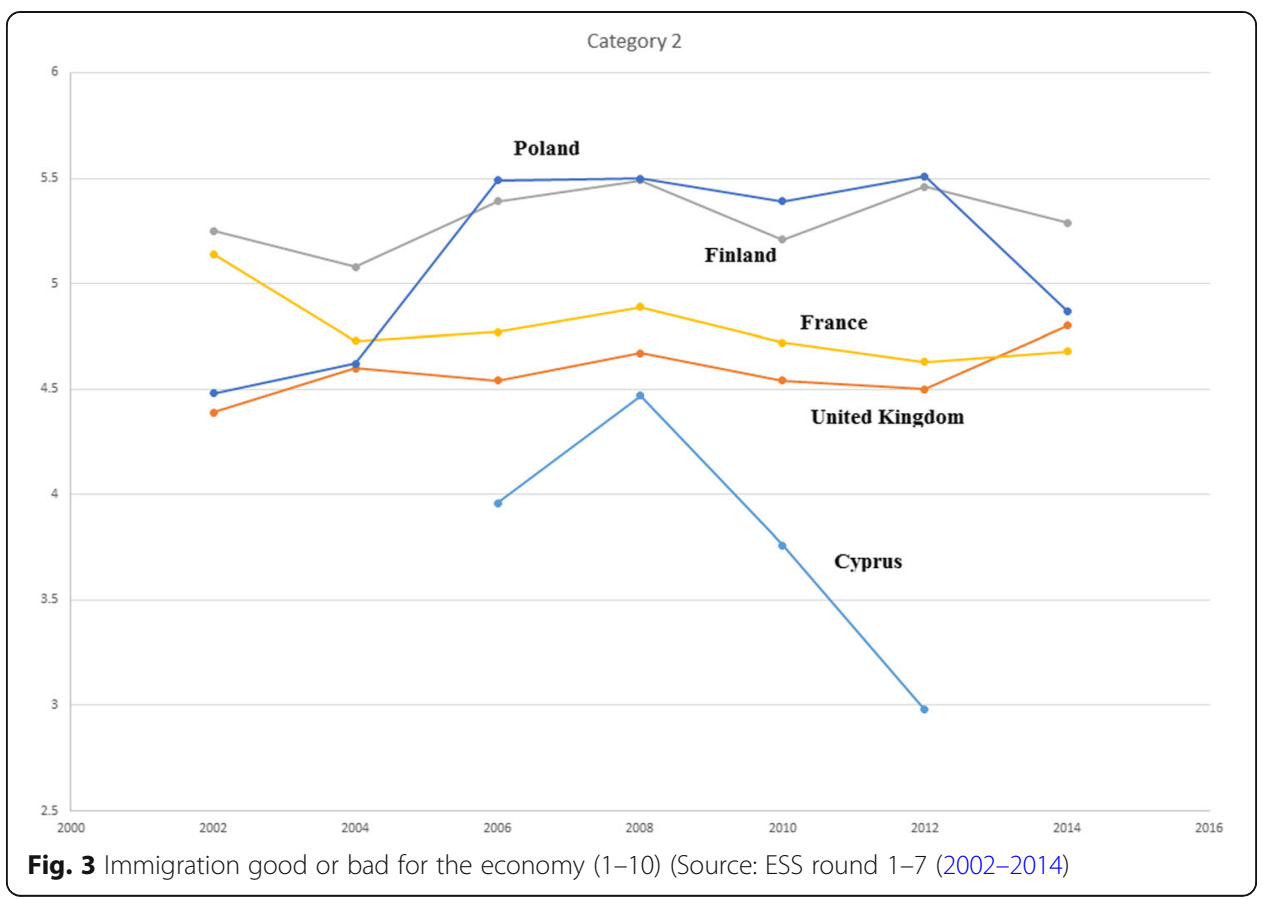

after the economy started to recover. German attitudes seem to be unaffected by the crisis despite experiencing a negative decline in GDP and in the unemployment rate (World Bank, 2017a, b, c). Since the reforms in immigration policy of the early 2000s, there has been a growing awareness of Germany as an immigration country. Since then there has been a strong commitment in the German population to making integration work. Incorporating migrants into the labor market and into the German society have also been federal priorities for the 10 years preceding the migration crisis (Abali, 2009). The crisis can be associated with an increase in negativ immigration attitudes in Slovenia, while more positive attitudes were prevalent in the period 2010-2012. While Slovenia experienced a considerable decline in GDP growth following the crisis, unemployment increased only moderately. This may indicate that it is not neceserraly GDP growth per se that is the most crucial indicator, and feelings of ethnic competition could rise as a result of an increase in unemployment. Slovenia and the Czech Republic display a similar pattern, where the crisis had a substantial negative effect on immigration attitudes especially after 2008. Interestingly, we can observe more positive attitudes in Slovenia than the Czech Republic despite a higher unemployment rate in Slovenia. Even so, the overall economic performance is slightly better in Slovenia, which may explain some of these differences. Czaika and Di Lillo (2018) have shown that the percentage of Slovenians with favorable attitudes to migrants from poorer countries outside Europe has declined by almost 4 percentage points in 2014 relative to 2002. They point out that there is also a trend in other European countries (for example Poland and The Netherlands) with more negative attitudes toward migrants from poorer countries outside Europe and more positive towards migrants of the same race or ethnic group. To sum up, the most prevalent finding in this group is the link between an increase in unemployment in Ireland and Czech Republic, and more skepticism toward immigration (Fig. 4). 


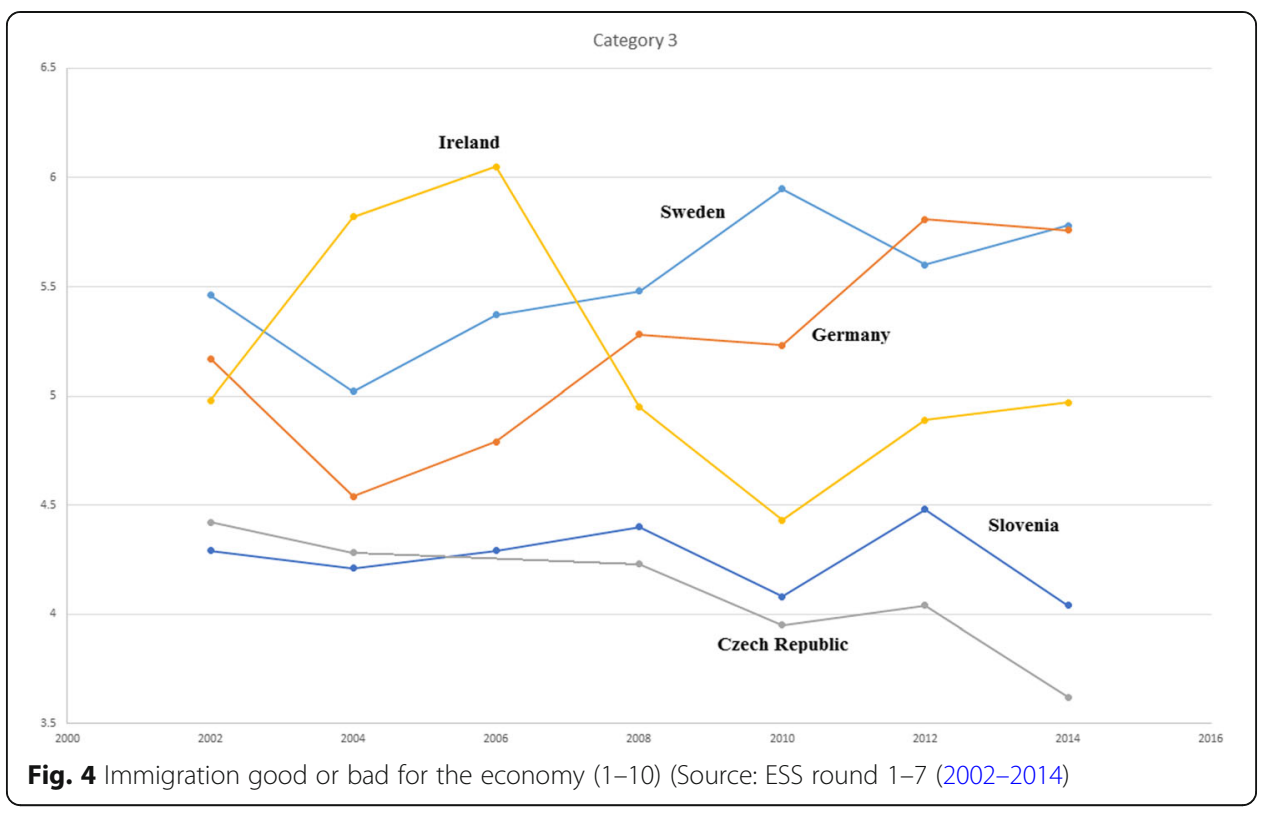

\section{Highly affected countries}

This category contains of countries where the crisis had a severe impact. Although, there are considerable variation in attitudes among these countries. Spain and Bulgaria displayed a quite similar trend, with a rather substantial increase of negative attidues. In Portugal, there were more positive attitudes leading up to the crisis, while more negative attitudes manifested after the outbreak of the crisis. This trend corresponds with a substantial increase in unemployment during the next two years. While Greece did not experience a dramatic decrease in GDP growth, it had a $50 \%$ increase in unemployment. Greece also experienced a huge increase in general government debt (World Bank, 2017a, b, and c). Greece is also a major point of entry for hundreds of thousands of illegal migrants into the European Union, and it may be that immigrants have become a convenient scapegoat in the aftermath of the financial crisis. Greece shows the same pattern as Spain, with unemployment being the strongest indicator of economic downturn. Negative attitudes towards immigration increased steadily from 2006 to 2010, reversing the opposite trend which took place from 2002 to 2006. Expect for Croatia, which also has had low immigration, all of the countries in this group have shown patterns of more skepticism toward immigration. The increase in negative attitudes was more prevalent among the countries that were the most severely affected by the crisis (Fig. 5).

\section{The most affected countries}

Category 5 shows large variations among the countries with the worst economic performance, although with some inconsistencies in the pattern. Ukraine, Russia and Estonia show a dramatic decline in growth, while in Estonia unemployment rates had a dramatic increase in the period 2007 to 2009. Even so, these countries show a stable pattern in attitudes towards immigration. One explanation could be that with the exception of Russia, these countries have experienced limited immigration. The low numbers of immigration in Eastern European can explain why immigration attitudes may 


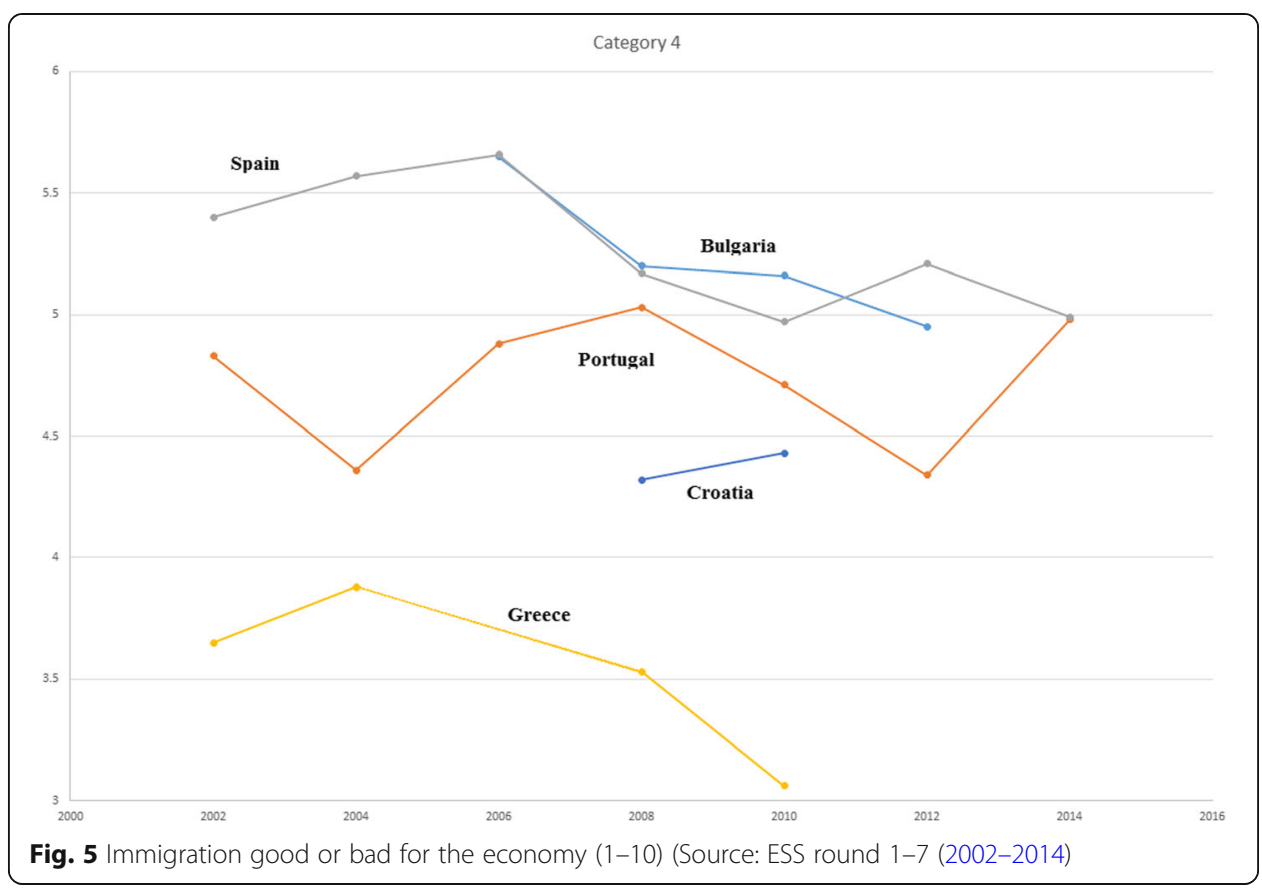

not be influenced to the same degree by economic fluctuations, when compared to countries with larger immigration. Overall, the largest groups of migrants in EU's Eastern European member states are also from countries that belonged to the Soviet Union and Yugoslav federations. Linguistic similarities and shared historical ties play a role among several of the Eastern European countries, and arguably this could explain why attitudes toward immigration in this region are generally more positive. In Ukraine the economic downturn seem to have had no effect on attitudes, while there was a moderate increase in negative attitudes in Estonia and Slovakia. Interestingly, Hungary showed an opposite pattern with more positive attitudes. It can be added that it may seem somewhat paradoxical that Hungary, which has had an uprising of support for the nationalist far right wing Jobbik party, does not show an increase in negative attitudes in this survey. In matters connected with immigrants, Jobbik's leaders are all-out opponents of accepting people from other cultural and religious circles into Hungary (Bartosz, 2017). However, having a high or low score on immigration attitudes is not automatically analogous to a rise in support for extreme fascist parties. Jobbik is known to be in opposition to refugees, and one could argue that this does not necessarily lead to overall skepticism toward labor immigration from neighboring countries (Fig. 6).

\section{Discussion}

From the descriptive data it is evident that many European countries have experienced that a negative shift in the economy goes along with more negative attitudes toward the immigration's contribution to the economy. Overall, the findings suggest that economic performance correlates with a change in attitudes. When the economy is stable or growing there are more positive attitudes, compared to when the economy is spiralling downwards. The descriptive data indicates that economic performance does influence immigration attitudes, especially in countries that were the most affected by the crisis. For the sake of capturing the time trends, I ran a descriptive analysis of attitudes 


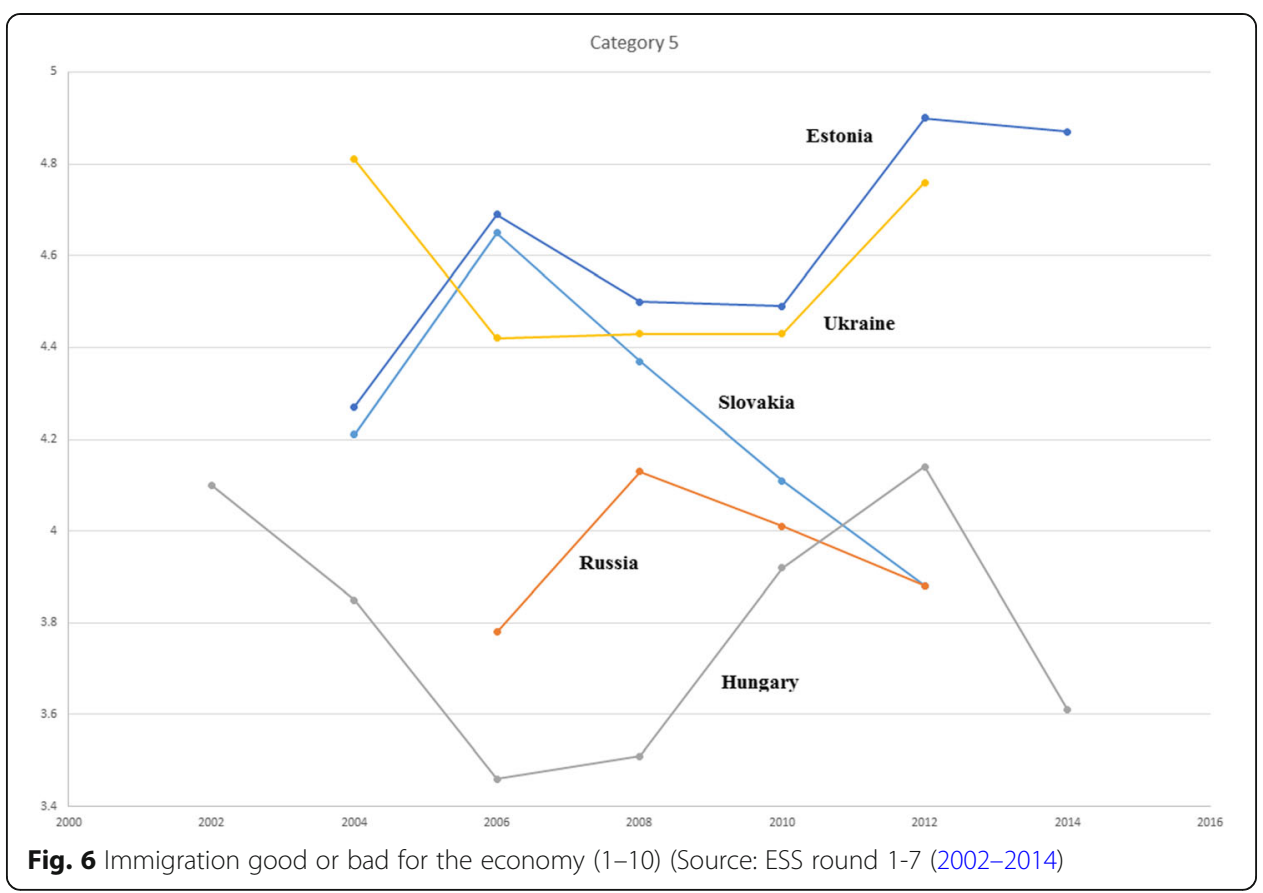

and analyzed them in view of indicators of economic development. This simple test provides some indication of the variations in attitudes in light of economic change.

The theoretical starting point of the study was Scapegoat theory as well as the intergroup contact- and the group threat theory. The aim was to analyze attitude formation over time at an individual and a country level. Through time series data I explored attitudes toward immigration across 25 European countries. I expected to find that those countries with the most stable economic development are associated with more positive attitudes toward immigrations' contribution to the economy. The observations show that both group threat-, scapegoat- and ethnic competition theory might explain why people tend to be more skeptic toward immigration during times of economic crisis. In those countries with best economic performance the attitudes toward immigration are also more positive. The complementary nature of both ethnic competition theory and intergroup contact theory, can be illustrated by the negative correlation between mediating mechanisms as well as the support for a curvilinear relationship between out-group size and perceived ethnic threat. These results suggest that the two theories may complement each other, where context is the most determining factor. For the purpose of this study, economic context serves as a mediating factor, deciding which of the mechanisms that is most important. In countries with the worst economic performance the results show an opposite pattern, thus giving support both to Scapegoat theory and group threat theory. Whether intergroup contact- or group threat mechanisms is at work thus depends on the country's economic situation. Building on the concept of post-materialism, it may be possible to connect the two theories, showing the specific circumstances under which the two competing theories exert the greatest explanatory power. Since the economic condition is an important explanatory factor, those countries with the worst economic performance during the crisis show the most negative attitudes. Countries with stable economic performance are also the most tolerant, which gives support to Inglehart (1977) who states that a positive economic 
development is linked with a move from absolute social norms toward tolerant, trusting, so-called post-modern values. People in these countries have adopted self-fulfilling values which moderate the majority's feelings of group threat. The surveys performed between 2002 and 2014 enabled me to compare the situation immediately prior to and immediately following the commencement of the economic crisis. It appears that some countries have developed more negative attitudes while others are more characterized by status quo. Countries with a stable economic performance over time, are not so affected by a sudden crisis. However, we see that a sudden large decline in GDP and an increase in unemployment often leads to an increase in negative attitudes, even in countries that leading up to the crisis were relatively stable. Ireland serves as a typical illustrative example of this, and suggests that changes in attitudes can be quite influenced by economic fluctuations. Stable economic performance seems to be an important indicator of high levels of tolerance toward immigration. One may argue that there are uncertainties linked to comparing the attitudes expressed by a historical event with the attitudes measured by a survey. Despite the potential flaw of causality, the descriptive data shows that countries with the lowest GDP before the crisis are those which display the highest rise in negative attitudes in the period following the crisis. The strongest economies seem to be less affected by a negative drop in GDP when it comes to attitudes.

\section{Conclusion}

This paper has examined European trends in attitudes toward immigration, and the the extent to which variations are associated with economic circumstances and concerns. The pattern is clear: the descriptive data indicates that scapegoating and feelings of group threat toward immigration may take place if they coincide with an economic downturn. By employing times series data of attitudes in combination with economic measures, the paper has investigated how economic standards, also referred to as development, can be a factor which explains variations over time. Overall, the empirical data from 25 European countries indicates that negative economic performance due to the 2007-2008 financial crisis coincided with more negative attitudes. Although, it is reasonable to assume that there are influences from national circumstances that are not only attributable to economic performance. There are for example variations between countries related to size of migrant workers, as well as the type of immigration. One could argue that high skilled labor can be perceived as a positive contribution to the economy, while low skilled labor from third world countries is perceived more negatively. The results show that the time variable was useful as this gave the opportunity to capture the variations both over time, and between countries. However, the crisis had a different economic impact on countries, especially between the more wealthy North- and Western European countries, compared to the Southern, and to some degree Eastern Europe. The data indicates that if a country is economically wealthy before the crisis, the impact of the economic downturn on attitudes will be relatively modest.This is especially prevalent among the countries in category 1 and 2 .

The main findings give support to both the scapegoat theory (Macionis \& Plummer, 2008), group threat- (Blalock, 1967), and ethnic competition theory (Savelkoul et al., 2011) since they all predict that economic downturn is expected to lead to more negative attitudes. According to scapegoat theory, a continuation of economic decline can 
lead to an increase in feelings of threat, a position that is supported by the data in this study. Economic downturns can in reality also lead to an increased struggle over resources, and if the economy continues to deteriorate, European countries may over time experience increased skepticism toward immigration. The majority population may in turn adopt more of the values associated with the survival dimension, which according to Inglehart (1997), has traditionally been more characteristic of non-Western societies. An economic decline can lead to more competition in the labor market over low-skill jobs, which in turn may lead to increased feelings of group threat, where people become increasingly sceptical of economic competition from immigrants over resources and jobs. If the unemployment rises and people experience fewer economic opportunities, it may potentially lead to a situation where immigrants are increasingly viewed as scapegoats. Both Blalock (1967) and Kinloch (1974) suggested that improved economic conditions contribute to improved ethnic relations and to diminished discriminatory attitudes. The data in this study suggest that even if a country displays a trend with positive immigration attitudes, these may quickly change if the country experiences a sudden economic downturn. Ireland is a striking example of this, where changes in attitudes quickly seemed to coincide with the economic crisis. Positive attitudes toward immigration seem to be related to stable economic conditions.

The findings presented in this study suggest that the financial crisis has increased European citizen's skepticism toward immigration, especially in the most affected countries. By employing commonly used economic indicators, I have been able to investigate several European countries over a longer time span. In sum, this study contributes to the understanding of the relationship between economic performance and immigrant attitudes, and how this particularly is related to a severe economic crisis. A crisis may contribute to increased opposition to immigration, and the rise of anti-immigration sentiment can be observed several years after the beginning of the crisis. In sum, this study contributes to the understanding of how economic performance may influence attitudes toward immigration. At the present stage, several years after the beginning of the crisis, many Europeans are still unemployed or underemployed. In some of the worst economically performing countries we also observe that the skepticism toward immigration continues long after the start of the crisis. Finally, although this study has examined one consistent question over time, questions that measure other dimensions could give a broader understanding of how attitudes towards immigration are related to economic fluctuations. Further research could also explore in more detail where and under what circumstances negative opposition toward immigration may occur.

Funding

The author declare to have no funding for this study.

Availability of data and materials

The datasets generated and/or analysed during the current study are available in the following repositories: Data from European Social Survey:

ESS Round 1: European Social Survey Round 1 Data (2002). Data file edition 6.5. NSD - Norwegian Centre for Research Data, Norway - Data Archive and distributor of ESS data for ESS ERIC.

ESS Round 2: European Social Survey Round 2 Data (2004). Data file edition 3.5. NSD - Norwegian Centre for Research Data, Norway - Data Archive and distributor of ESS data for ESS ERIC.

ESS Round 3: European Social Survey Round 3 Data (2006). Data file edition 3.6. NSD - Norwegian Centre for Research Data, Norway - Data Archive and distributor of ESS data for ESS ERIC.

ESS Round 4: European Social Survey Round 4 Data (2008). Data file edition 4.4. NSD - Norwegian Centre for Research Data, Norway - Data Archive and distributor of ESS data for ESS ERIC.

ESS Round 5: European Social Survey Round 5 Data (2010). Data file edition 3.3. NSD - Norwegian Centre for Research Data, Norway - Data Archive and distributor of ESS data for ESS ERIC. 
ESS Round 6: European Social Survey Round 6 Data (2012). Data file edition 2.3. NSD - Norwegian Centre for Research Data, Norway - Data Archive and distributor of ESS data for ESS ERIC.

ESS Round 7: European Social Survey Round 7 Data (2014). Data file edition 2.1. NSD - Norwegian Centre for Research Data, Norway - Data Archive and distributor of ESS data for ESS ERIC.

World Bank Data:

World Bank. (2017). GDP per capita growth (annual \%). Available at: http://data.worldbank.org/ (Downloaded 06.10.2017). World Bank. (2017). Unemployment (yearly in percent). Available at http://data.worldbank.org/ (Downloaded 06.10.2017). World Bank. 2017. GDP per capita (current US\$). Available at http://data.worldbank.org/ (Downloaded 06.10.2017). The data that support the findings of this study are available from ESS and The World Bank. but restrictions apply to the availability of these data, which were used under license for the current study, and so are not publicly available. Data are however available from the authors upon reasonable request and with permission of Joachim Vogt Isaksen.

\section{Author's contributions}

The author read and approved the final manuscript.

\section{Competing interests}

The author declares that he has no competing interests.

\section{Publisher's Note}

Springer Nature remains neutral with regard to jurisdictional claims in published maps and institutional affiliations.

\section{Received: 10 July 2018 Accepted: 17 February 2019}

Published online: 13 June 2019

\section{References}

Abali, O. S. (2009). German public opinion on immigration and integration. Washington: Migration Policy Institute.

Allport, G. W. (1954). The nature of prejudice. Reading: Addison-Wesley.

Bartosz, B. (2017). Ideology of the Hungarian far right on the example of Jobbik, the movement for a better Hungary. Ante Portas - Studia nad Bezpieczeństwem, 2(9), 201-2013.

Blalock, H. M. (1967). Toward a theory of minority-group relation. New York: Wiley.

Blanchard, O. (2006). Macroeconomics, (5th ed., ). Jersey: Pearson International edition: Pearson Education.

Blumer, H. (1958). Race prejudice as a sense of group relation. Pacific Sociological Review, 1, 3-7.

Borjas, G. J., \& Freeman, R. B. (Eds.) (1992). Immigration and the work force: Economic consequences for the United States and source areas. Chicago: The University of Chicago Press.

Coenders, M., \& Scheepers, P. (1998). Support for ethnic discrimination in the Netherlands 1979-1993: Effects of period, cohort, and individual differences. European Sociological Review, 14(4), 405-422.

Coenders, M., \& Scheepers, P. (2008). Changes in Resistance to the Social Integration of Foreigners in Germany 1980-2000: Individual and Contextual Determinants. Journal of Ethnic and Migration Studies, 34(1), 1-26. https://doi.org/10.1080/13691830701708809.

Czaika, M., \& Di Lillo, A. (2018). The geography of anti-immigrant attitudes across Europe, 2002-2014. Journal of Ethnic and Migration Studies, 44(15), 2453-2479.

Dancygier, R., \& Donnelly, M. (2014). Attitudes toward immigration in good times and bad. In L. Bartels, \& N. Bermeo (Eds.), Mass Politics in Tough Times: Opinions, votes and protest in the great recession. Oxford: Oxford University Press https://doi.org/10.1093/acprof:oso/9780199357505.001.0001.

Day, C. L. (1990, April 5-7). Ethnocentrism, economic competition, and attitudes toward U.S. immigration policy. Chicago: Paper presented at the Annual Meeting of the Midwest Political Science Association. Chicago, IL.

Espenshade, T. J., \& Hempstead, K. (1996). Contemporary American attitudes toward U.S. immigration. International Migration Review, 30(2), 535-570

ESS Round 1-7: European Social Survey Round 1-7 (2002-2014). NSD - Norwegian Centre for Research Data, Norway - Data Archive and distributor of ESS data for ESS. ERIC.

Evans, G., \& Need, A. (2002). Explaining ethnic polarization over attitudes toward minority rights in Eastern Europe: a multilevel analysis. Social Science Research, 31, 653-680.

Fosset, M. A., \& Kiecolt, K. J. (1989). The relative size of minority populations and white racial attitudes. Social Science Quarterly, 70(4), 820-835.

Gijsberts, M., Scheepers, P., \& Coenders, M. (2004). Exclusion of legal migrants in Western Europe. In M. Gijsberts, L. Hagendoorn, \& P. Scheepers (Eds.), Nationalism and exclusion of migrants: Cross-National Comparison, (pp. 121-142). Aldershot: Ashgate.

Gurr, T.R. (2011). Why Men Rebel. Boulder: Paradigm Publishers.

Hernes, G., \& Knudsen, K. (1992). Norwegians attitudes toward new immigrants. Acta Sociologica, 35(2), 123-139.

Hoskin, M. \& Mishler, W. (1983). Public opinion toward new migrants: a comparative analysis. International Migration, 21(4), 440-462.

Inglehart, R. (1977). The silent revolution: changing values and political styles in advanced industrial society. Princeton: Princeton University Press.

Inglehart, R. (1990). Culture shift in advanced industrial society. Princeton: Princeton University Press.

Inglehart, R. (1997). Modernization and Postmodernization: Cultural, economic, and political change in forty-three societies. Princeton: Princeton University Press.

Jackson, J. W. (1993). Realistic group conflict theory: a review and evaluation of the theoretical and empirical literature. Psychological Record, 43(3), 395-415.

Kehrberg, J. E. (2007). Public opinion on immigration in Western Europe: economics, tolerance, and exposure. Comparative European Politics, 5(3), 264-282.

Kinloch, G. (1974). The dynamic of race relations: a sociological analysis. New York: McGraw-Hill. 
Kroknes, V. F., Jakobsen, T. G., \& Grønning, L.-M. (2015). Economic performance and political trust: the impact of the financial crisis on European citizens. European Societies, 17(5), 700-723.

Krugman, P. (2009). The return of depression economics - and the crisis of 2008. New York: W.W. Norton \& Company, Inc. Krugman, P. (2012). End This Depression Now! W. W. Norton \& Company.

Kunovich, R. M. (2004). Social structural position and prejudice: an exploration of cross national differenced in regression slopes. Social Science Research, 33(1), 20-44

Latané, B. (1981). The psychology of social impact. American Psychologist, 36(4), 343-356.

Macionis, J. J., \& Plummer, K. (2008). Sociology. A global introduction, (4th ed.). ). Harlow: Pearson Education Limited.

Mayda, M. M. (2006). Who is against immigration? A Cross-country investigation of individual attitudes toward immigrants. Review of Economics and Statistics, 88(3), 510-530.

Meuleman, B., Davidov, E., \& Billiet, J. (2009). Changing attitudes toward immigration in Europe, 2002-2007: a dynamic group conflict theory approach. Social Science Research, 38(2), 352-365.

Moehring, H. B. (1988). Symbol versus substance in legislative activity: the case of illegal immigration. Public Choice, 57(3), 287-294.

Olzak, S. (1992). The dynamics of ethnic competition and conflict. Stanford, California: Stanford University Press.

Pear, R. (1986). New restrictions on immigration gain public support, Poll Shows. New York: The New York Times.

Peri, G. (2010, June 10). The impact of immigrants in recession and economic expansion. Migration Policy Institute. Retrieved from https://www.hsdl.org/c/the-impact-of-immigrants-in-recession-and-economic-expansion/

Quillian, L. (1995). Prejudice as a response to perceived group threat: Population composition and anti-immigrant and racial prejudice in Europe. American Sociological Review, 60(4), 586-611.

Raijman, R., Semyonov, M., \& Schmidt, P. (2003). Do foreigners deserve rights? Determinants of public opinion views toward foreigners in Germany and Israel. European Sociological Review, 19(4), 379-392.

Roth, F. (2009). The effect of the financial crisis on systemic trust. Intereconomics, 44(4), 203-208. http://dx.doi.org/10.1007/ s10272-009-0296-9. Retrieved from https://www.econstor.eu/bitstream/10419/66173/1/727030833.pdf.

Runciman, W. G. (1966). Relative deprivation and social justice: a study of attitudes to social inequality in twentieth-century England. Berkeley: University of California Press.

Savelkoul, M., Scheepers, P., Tolsma, J., \& Hagendoorn, L. (2011). Anti- Muslim attitudes in the Netherlands: Tests of contradictory hypotheses derived from ethnic competition theory and intergroup contact theory. European Sociological Review, 27(6), 741-758.

Scheepers, P., Gijberts, M., \& Coenders, M. (2002). Ethnic exclusionism in European countries: Public oppositions to civil rights for legal migrants as a response to perceived threat. European Sociological Review, 18(1), 17-34.

Scheve, K. F., \& Slaughter, M. J. (2001). Labor market competition and individual preferences over immigration policy. The Review of Economics and Statistics, 83(1), 133-145.

Semyonov, M., Raijman, R., \& Gorodzeisky, A. (2006). The rise of anti-foreigner sentiment in European societies, 1988-2000. American Sociological Review, 71(3), 426-449.

Semyonov, M., Raijman, R., Yom-Tov, A., \& Schmidt, P. (2004). Population size, perceived threat and exclusion: A multiple indicator analysis of attitudes toward foreigners in Germany. Social Science Research, 33(4), 681-701.

Simon, R. J. (1987). Immigration and American attitudes. Public Opinion, 10(2), 47-50.

Turner, T., \& Cross, C. (2015). Do attitudes to immigrants change in hard times? Ireland in a European context. European Societies, 17(3), 372-395. https://doi.org/10.1080/14616696.2015.1035298.

World Bank. (2017a). GDP per capita growth (annual \%). Retrieved 6 October, 2017 from http://data.worldbank.org/

World Bank. (2017b). Unemployment (yearly in percent). Retrieved 6 October, 2017 from http://data.worldbank.org/

World Bank. (2017c). GDP per capita (current US\$). Retrieved 6 October, 2017 from http://data.worldbank.org/

\section{Submit your manuscript to a SpringerOpen ${ }^{\circ}$ journal and benefit from:}

- Convenient online submission

- Rigorous peer review

- Open access: articles freely available online

- High visibility within the field

- Retaining the copyright to your article

Submit your next manuscript at $\boldsymbol{\nabla}$ springeropen.com 